OPEN ACCESS

Edited by:

James Blande,

University of Eastern Finland, Finland

Reviewed by:

Drew Peltier,

Northern Arizona University,

United States

Anirban Guha,

University of Florida, United States

*Correspondence:

Walter Oberhuber

walter.oberhuber@uibk.ac.at

Specialty section:

This article was submitted to

Forest Ecophysiology,

a section of the journal

Frontiers in Forests and Global

Change

Received: 28 June 2021 Accepted: 07 October 2021

Published: 04 November 2021

Citation:

Schröter DM and Oberhuber W

(2021) Do Growth-Limiting

Temperatures at the High-Elevation

Treeline Require an Adaptation

of Phloem Formation and Anatomy?

Front. For. Glob. Change 4:731903.

doi: 10.3389/ffgc.2021.731903

\section{Do Growth-Limiting Temperatures at the High-Elevation Treeline Require an Adaptation of Phloem Formation and Anatomy?}

\author{
Dennis Marko Schröter and Walter Oberhuber* \\ Department of Botany, Leopold-Franzens-University of Innsbruck, Innsbruck, Austria
}

Low temperatures during the growing season restrict the growth of trees at high elevations and lead to the formation of the high-elevation treeline. To ensure the survival and growth of trees in such extreme locations, sufficient vascular transport capacity - enabled by vascular anatomical characteristics - is required. However, in contrast to the xylem, only little is known about the effects of low temperatures on the anatomy and formation of the phloem as important nutrient- and signal-conducting tissue. In this review, known findings of cold-induced changes in the anatomical and phenological properties of vascular tissues are used as starting points to discuss how low temperatures might affect phloem formation at the treeline and how this conductive tissue might adaptively respond to this growth-limiting environmental variable. Data currently available suggest that low temperatures lead to changes in the anatomy and phenological development of the phloem. In order to ensure the functionality of the phloem and thus the survival of trees at the high-elevation treeline, appropriate adaptations to the prevailing low temperatures are therefore to be expected and are discussed in this review.

Keywords: adaptation, intra-annual phloem formation, low temperature, phloem anatomy, phloem transport, phenology, tree growth, treeline

\section{INTRODUCTION}

Phloem is a highly complex vascular tissue that performs numerous functions for the growth and survival of trees. The long-distance transport of both phytohormones and RNAs as information signals between above- and belowground tissues (Lacombe and Achard, 2016; Kondhare et al., 2021) and carbohydrates as nutrients from source to sink (Savage et al., 2016) are considered to be important key functions, enabled by the anatomical properties of phloem (Schulz and Thompson, 2009; Knoblauch and Oparka, 2012; Liesche et al., 2015). The characteristics of the phloem in trees differ from those in herbaceous plants (for more details see De Schepper et al., 2013 and the literature therein). Phloem transport occurs along three functional units (i.e., collection, transport, and release phloem) via sieve cells and sieve tube elements in gymnosperms and angiosperms, respectively (van Bel, 2003; De Schepper et al., 2013). The water required for phloem transport is provided by the radial connection to the xylem via ray parenchyma (Box 1; Hölttä et al., 2009; Pfautsch et al., 2015; Sevanto, 2018). In this process, ray parenchyma cells provide not only the radial transport of water and carbohydrates between xylem and phloem (van Bel, 1990) but also 
in and out of the axial parenchyma tissue (Pfautsch et al., 2015). Sieve elements and companion cells are laterally connected via sieve areas consisting of several sieve pores. Axially, sieve elements are connected by sieve areas in gymnosperms, which form a sieve plate with large sieve pores in angiosperms (Liesche et al., 2017). During the growing season, there is a transition from early phloem cells with wide lumen that have a conducting function to late phloem cells with narrow lumens that primarily have a storage function (Gričar et al., 2021). These phloem cells are separated by a band of axial parenchyma cells (Figure 1; Gričar and Čufar, 2008).

Although both the xylem and phloem arise from radial cell division of the cambium (Larson, 1994), the formation of both tissues is not synchronous and is driven by different factors (Prislan et al., 2013; Gričar et al., 2015, 2021). In contrast to the xylem, the phloem was found to be less susceptible to environmental influences and mainly endogenously controlled (Alfieri and Evert, 1968; Rosner et al., 2001; Gričar and Čufar, 2008; Prislan et al., 2013; Swidrak et al., 2014; Miller et al., 2020; Gričar et al., 2021). Even before the reactivation of cambial activity after dormancy, phloem formation starts with expansion and differentiation of overwintered phloem cells (Alfieri and Evert, 1968, 1973; Antonova and Stasova, 2006; Gričar and Čufar, 2008). After the reactivation of the cambium, the onset of phloem cell production precedes xylem production by approximately 2-3 weeks (Alfieri and Evert, 1968; Antonova and Stasova, 2006, 2008; Swidrak et al., 2014; Jyske et al., 2015), due to the short functional life span of sieve cells of 1-2 years before they collapse (Evert, 2006).

Because climate change strongly affects tree growth and the phloem fulfills important functions in carbon allocation, phloem anatomy and phenology gained increasing importance in the last decade (e.g., Liesche et al., 2015, 2017; Miller et al., 2020; Gričar et al., 2021). Surprisingly, no studies were published yet dealing with intra-annual development and anatomy of phloem cells at high-elevation treeline sites, where trees reach their uppermost distributional limit due to temperature constraints on tree growth. Globally, trees at high-elevation treelines are exposed to seasonal mean air temperature between 5.5 and $7.5^{\circ} \mathrm{C}$ (Körner, 1998). In this brief review, we will evaluate possible adaptations in phloem phenology and anatomy under low temperatures.

\section{TEMPERATURE LIMITATION OF TREE GROWTH AT HIGH ELEVATIONS}

Low temperatures are considered to be the main reason for the upper distributional boundary of trees (e.g., Körner and Paulsen, 2004; Rossi et al., 2007; Caccianiga et al., 2008; Körner, 2015). Only a few taxa are able to reach the uppermost highelevational limit for trees - the treeline - which is a conspicuous climate-driven ecological boundary and occurs worldwide at high elevations (Körner, 2012). In the temperate climate zone, conifers of the genera Pinus, Larix, and Picea, as well as tree species belonging to Betulaceae and Fagaceae, are among the most successful tree taxa dominating at the high-elevation treeline (e.g., Körner and Paulsen, 2004; Caccianiga et al., 2008; Körner, 2012; Leuschner and Ellenberg, 2017).

At high elevations, the meristem activity, i.e., cell division, enlargement, and differentiation, is more sensitive to lowtemperature conditions prevailing during the growing season than photosynthesis. The "carbon-sink-limitation hypothesis" is currently the most widely accepted hypothesis for explaining the formation of treelines (e.g., Körner and Paulsen, 2004; Rossi et al., 2007; Körner, 2015). While photosynthesis is still active at temperatures near the freezing point (e.g., Häsler, 1982; Weng et al., 2005), the exponential increase in cell doubling time below c. $5^{\circ} \mathrm{C}$ causes the upper elevational limit for the occurrence of trees (Körner, 2003, 2015). Numerous studies revealed that both aboveground and belowground growth is strongly reduced at temperatures below $5^{\circ} \mathrm{C}$ (Häsler et al., 1999; Alvarez-Uria and Körner, 2007, 2011; Rossi et al., 2007, 2008; Schenker et al., 2014). All growth processes, i.e., root, radial stem, and shoot growth as well as budburst, and subsequent leaf and flower development require water, carbon compounds, nutrients, and hormones via the vascular system, i.e., phloem and xylem (Savage and Chuine, 2021). Several findings have already demonstrated the effects of low temperatures on the xylem, i.e., reductions in wood formation, cell diameter, and cell wall thickness (e.g., Rossi et al., 2007, 2008; Castagneri et al., 2017; Babushkina et al., 2019). Therefore, it is necessary to consider low-temperature influences at high elevations on the anatomical characteristics and phenology of the phloem to comprehensively understand temperature-induced growth limitation.

\section{ARE CARBON AVAILABILITY AND PHLOEM TRANSPORT REDUCED AT THE HIGH-ELEVATION TREELINE?}

A continuous supply of carbohydrates is essential for tree growth (Cuny et al., 2015; Deslauriers et al., 2016), especially under extreme climatic conditions prevailing at the treeline. Several authors have shown that photosynthesis is less limited by low temperatures than growth (Grace et al., 2002, for a review, see Körner, 2015). Larcher (2003) reported that photosynthetic production in evergreen conifers commences at temperatures between -5 and $-3^{\circ} \mathrm{C}$. An excess of these assimilates are stored as non-structural carbohydrates (Box 1; NSC) like starch and other carbon compounds (sugar, alcohol, lipids, proteins) which can be later mobilized for growth, development, and regeneration (Palacio et al., 2014). Several studies have shown an increasing trend in the content of NSC in leaves, stem, and root along an elevational transect, i.e., decrease in air temperature, up to the treeline (e.g., Hoch et al., 2002; Hoch and Körner, 2003, 2009; Gruber et al., 2011). An increase in NSC storage is considered as an immediate physiological response to low temperatures and to compensate for the imbalance between carbon production and demand (Hoch and Körner, 2012).

As mentioned above, root growth decreases at temperatures below $5^{\circ} \mathrm{C}$ (Alvarez-Uria and Körner, 2007, 2011; Schenker et al., 2014). However, at the treeline, reduced nutrient availability due to low nutrient mineralization rates (e.g., Meentemeyer, 1977) 
BOX 1| Glossary of terms.

Axial parenchyma: Longitudinally arranged parenchyma cells for vertical transport and storage of carbohydrates.

Callose: Polysaccharide ( $\beta$-1,3-glucan) found in cell walls of higher plants; involved in phloem transport and deposited as response to injury.

Companion cells: Specialized nucleated parenchyma cells regulating transport of substances in and out of sieve elements.

Early phloem: First formed phloem cells with large diameter primarily for transport of substances.

Initial early phloem: Undifferentiated overwintering cells formed at the end of the previous growing season, which differentiate to early phloem in spring.

Late phloem: Formed after early phloem with narrow diameter primarily for storage.

Non-structural carbohydrates: Comprise primarily soluble sugars and starch; provide substrates for growth, metabolism and osmoregulation.

Sieve area: Are developed in axial and lateral cell walls between sieve elements and between sieve elements and companion cells, respectively.

Sieve elements: Enucleate functional units for phloem transport connected via sieve plates and/or sieve areas.

Sieve plate: Are developed in angiosperms in transverse cell walls between axial connected sieve elements (cf., Figure 1).

Sieve pores: Pores lined with callose within sieve areas and sieve plates (cf., Figure 1).

Ray parenchyma: Radially arranged parenchyma cells for storage and lateral transport of water and carbohydrates between xylem and phloem.

as well as cold-related physical constraints in water and nutrient uptake from soil to root (Weih and Karlsson, 2001, 2002) require appropriate adaptive responses for an efficient nutrient uptake. In this regard Hertel and Schöling (2011) found an increase of fine root biomass with elevation in Norway spruce (Picea abies) resulting in a higher root to shoot ratio. Additionally, Kubisch et al. (2017) demonstrated an accelerated fine root turnover and higher production rate in Pinus cembra under soil temperatures lowered by self-shading, which underpin the previous results. This implies both a sufficient carbon availability and an efficient phloem transport in favor of root growth to ensure an adequate nutrient uptake at the treeline. Hence, phloem is able to remain functional even at the world's highest treeline formed by Polylepis sp. at c. 5,000 m a.s.l. (Hoch and Körner, 2005).

\section{EXPECTED ADAPTATIONS OF PHLOEM ANATOMY AND PHENOLOGY AS A RESPONSE TO EXTREME CLIMATE CONDITIONS AT THE HIGH-ELEVATION TREELINE}

In field experiments, several authors found that phloem formation and anatomy are less responsive to variability in environmental conditions compared to the xylem (Alfieri and Evert, 1968; Rosner et al., 2001; Gričar et al., 2014; Swidrak et al., 2014; Miller et al., 2020). However, extreme climate conditions might impair intra-annual phloem formation and/or phloem anatomy which would adversely affect carbon transport and dependent metabolic processes such as growth and development (e.g., Savage and Chuine, 2021). Salmon et al. (2019) described in detail the anatomical constraints of phloem under severe drought, whereas species-specific effects on phloem anatomy at low soil water availability were shown by Epron et al. (2019). This raises the question of how low temperatures can affect phloem formation and anatomy.

In a cooling treatment in the field, it was found that low temperatures $\left(9-11^{\circ} \mathrm{C}\right)$ resulted in reduced cambial activity, indicated by a lower proportion of latewood in Picea abies, while the phloem anatomy and width of growth increments remained unaffected (Gričar et al., 2006). However, long-term cooling of a stem portion of Picea abies caused not only a significant reduction in cambial activity but low temperatures also led to anatomical alterations on the phloem side (Gričar et al., 2007). Specifically, early phloem was less affected, but the tangential band of axial parenchyma separating the early and late phloem was no longer continuous and the number of late phloem cells was reduced. Similar results were found at mid-elevation sites in Picea abies (1,200 m a.s.l.; Gričar et al., 2015, 2021). Based on these studies, it can be expected that comparable effects occur at the highelevation treeline (Figure 1).

\section{Does the Temperature-Induced Reduction in Cambial Activity Also Affect Phloem Anatomical Features?}

Based on several studies on coniferous species, temperatureinduced changes in xylem anatomy affect cell size, as well as cell wall thickness, the latter being related to carbon mobilization and deposition rates (e.g., Rossi et al., 2008; Lupi et al., 2010; Körner, 2012). Castagneri et al. (2017) and Babushkina et al. (2019) demonstrated along an elevational gradient, that low temperatures especially at high elevations are one of the key climatic factors affecting xylem cell enlargement and cell wall deposition, which subsequently are reflected in a reduction of cell diameter and cell wall thickness. Similar effects on phloem anatomy are to be expected at the treeline, where low temperatures prevail during the growing season (Figure 1). Moreover, it should be noted that possible low-temperature effects on phloem formation and anatomy may impair the carbon transport in some tree species. Liesche et al. (2015) demonstrated in their study a lower phloem transport rate in narrow sieve cells of gymnosperms compared to angiosperms, which supports this assumption. Additionally, Pfautsch et al. (2015) reported that phloem sap becomes increasingly viscous with decreasing temperature, which additionally increases resistance in phloem transport. Because at high elevation xylem cells were found to be highly vulnerable to cavitation (Mayr et al., 2002, 2003), impaired phloem transport could also have an impact on the repair of embolized xylem cells (cf., Pfautsch et al., 2015).

\section{How Can Phloem Transport Efficiency Be Ensured Under Low Temperatures Prevailing at the High-Elevation Treeline?}

Several findings conducted at mid-elevation sites $(1,200 \mathrm{~m}$ a.s.l., Gričar et al., 2014, 2015, 2021; Miller et al., 2020) 


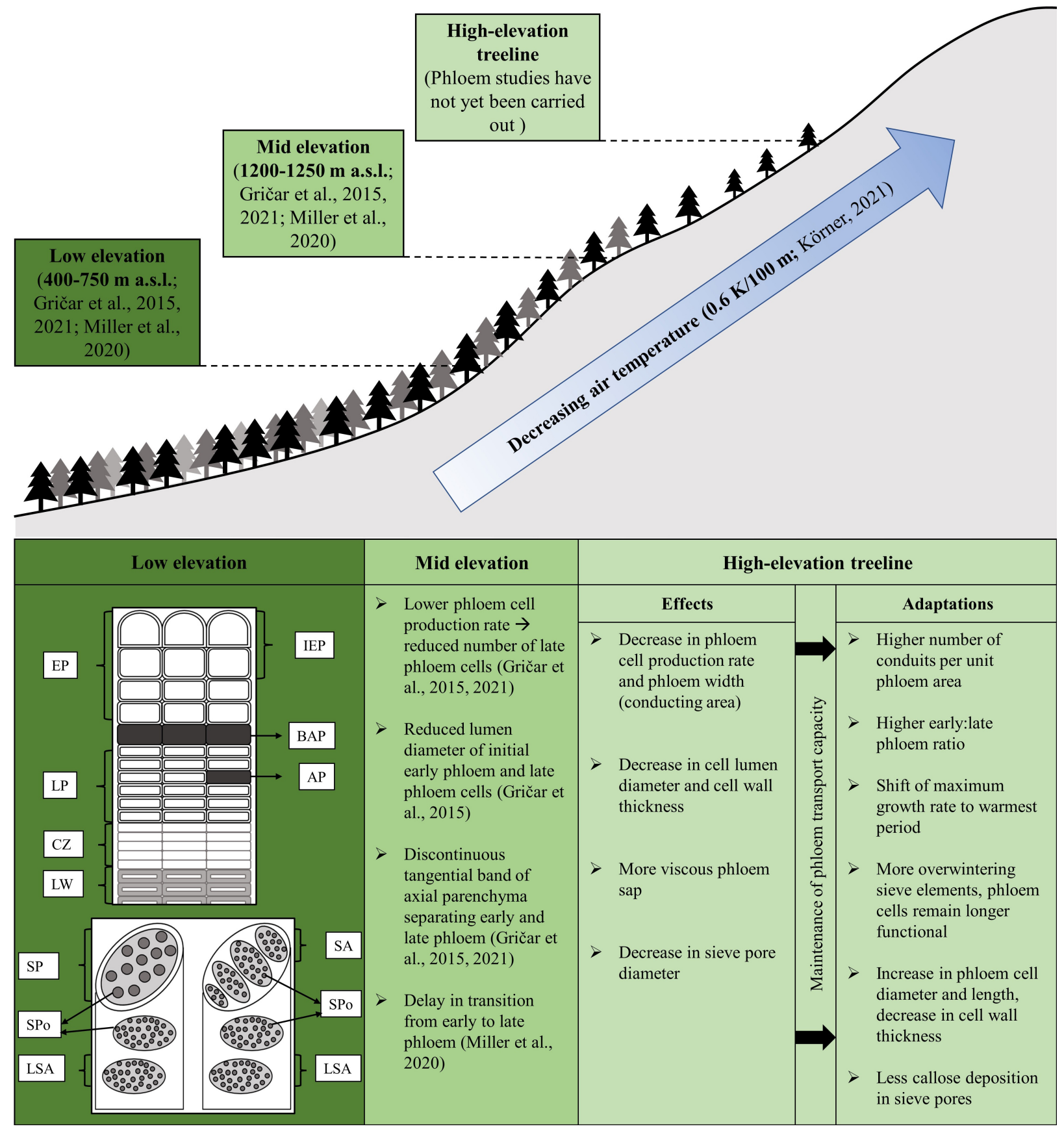

h-elevation

treeline

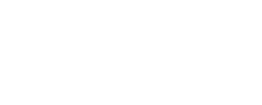

Mid elevation

Gričar et al., 2015,

Miller et al. 
more strongly restricted than radial stem growth (Hoch and Körner, 2005; Körner, 2012; Wang et al., 2012). Therefore, it can be assumed that phloem responds with an increase in cell density resulting in an increased ratio of early to late phloem cells for better conductivity. The priority of the early phloem as the conductive part over the late phloem (storage) is shown by its robustness to environmental influences and underpins its greater importance for the survival of trees (Larson, 1994; Gričar et al., 2015, 2021). Temperaturerelated changes in radial dimension (lumen) of initial early phloem (Box 1; i.e., first tangential rows of cells at the phloem growth ring boundary formed in the previous year) and late phloem cells (Gričar et al., 2015), as well as a seasonal variability in length of sieve elements and axial parenchyma (Jyske et al., 2015), suggest an adaptive change in cell size for an efficient conductivity under low temperatures. Furthermore, several authors reported a decrease in cell wall thickness in earlywood and latewood tracheids at mid elevations (1,260 m a.s.l., Gindl et al., 2001; 1,200 $\mathrm{m}$ a.s.l., Gričar et al., 2015), and a similar effect in sieve cell wall thickness could be conceivable as another way to increase the sieve cell lumen diameter at high elevations. However, the conductive capacity of the phloem at the treeline may be favored not only by adaptations in the aforementioned anatomical traits but also by an increase in sieve pore size and frequency along the pathway (Mullendore et al., 2010). Sieve pores can be lined with callose or nearly occluded with it, which may play a significant role in transport regulation through the symplast (Neuberger and Evert, 1975; Knoblauch and van Bel, 1998). Callose is deposited as a response to cell injury, senescence, or dormancy (Evert, 1990) whereby not all pores are sealed with it (Montwe et al., 2019; Prislan et al., 2019). Due to the prevailing extreme climate conditions at the high-elevation treeline, less callose might accumulate as a temperature-dependent response to increase sieve pore size and create less resistance to ensure phloem transport capacity (cf., McNairn, 1972). Because of the severely time-limited lifespan of sieve elements, the priority for tree survival is in phloem production while xylem thickness can be reduced or become discontinuous (Evert, 2006). Especially under extreme environmental conditions, this is reflected in a lower xylem to phloem ratio (Larson, 1994; Plomion et al., 2001; Gričar et al., 2009).

Phenological adaptations can also influence anatomical properties of vascular tissues in favor of functional capacity, as demonstrated by Cuny et al. (2019). It became apparent, that in cold environments xylem differentiation rate (i.e., cell elongation and cell wall thickening) decreased but to mitigate the influence of low temperatures the duration of these processes was extended. Miller et al. (2020) reported a delay in the transition from early to late phloem in Picea abies along an elevational gradient extending from $450 \mathrm{~m}$ to $1,250 \mathrm{~m}$ a.s.l., which was related to the onset of cambial activity, cell production rate, and the number of cells in the early phloem. Findings in this study also provide the first evidence that in contrast to xylem formation (e.g., Rossi et al., 2006) maximum phloem cell production rate does not coincide with the summer solstice. These results suggest that at the high-elevation treeline the maximum phloem growth rate may shift to the warmest period instead of being controlled by photoperiod or endogenous factors. Furthermore, it is conceivable that more overwintering phloem cells are formed or that phloem cells remain functional for more than one to two growing seasons, which would correspond to the observations of Holdheide (1951). Hence, adaptations in intra-annual phloem formation and anatomy in response to low temperatures and climate extremes (e.g., the occurrence of frost drought) prevailing at the high-elevation treeline are to be expected (Figure 1; cf., Agusti and Greb, 2013; Gričar et al., 2015, 2021; Miller et al., 2020). This would also entail a shift from endogenous to exogenous control of phloem formation.

\section{AREAS OF FUTURE RESEARCH}

Expected adaptations of phloem phenology and anatomy induced by extreme climatic conditions prevailing at the high-elevation treeline are shown in Figure 1. In order to understand the effects of low temperatures on the phloem at high elevations, several questions need to be clarified, e.g., (i) How does phloem phenology and anatomy adapt to climate extremes (e.g., cold summer with shortened growing period, early or late frost events) at the treeline? (ii) To what extent is phloem transport capacity and efficiency affected by low temperatures? (iii) Is tip-to-base widening occurring at treeline (cf., Jyske and Hölttä, 2015; Ryan and Robert, 2017)? (iv) Are there organ specific differences in phloem formation and anatomy, e.g., in branches (twigs) vs. roots due to exposure to different temperature regimes, i.e., high vs. low daily temperature variability? (v) How sensitive is phloem formation to environmental stress (e.g., frost drought) within the treeline ecotone? (vi) Is there a yearto-year variability in phloem formation depending on weather conditions or does endogenous control of phloem formation also predominate at the high-elevation treeline? A combination of high measurement frequency and longterm observations in the field together with field chilling experiments, laboratory manipulations, and histo-anatomical analyses will be necessary to answer these questions. As there are differences in phloem anatomy between gymnosperms and angiosperms (Jensen et al., 2012; Liesche et al., 2015, 2017) the question arises if species-specific adaptations regarding phloem anatomy and/or phenology at the high-elevation treeline occur.

\section{CONCLUSION}

Phloem fulfills important functions for tree growth and development (Hölttä et al., 2009; Pfautsch et al., 2015; 
Sevanto, 2018). However, compared to the xylem much less is known about the influence of growth-limiting temperatures at high elevations on the anatomy and intraannual formation of the phloem. Therefore, to advance our knowledge about the characteristics of phloem tissue at the high-elevation treeline, field and experimental studies are urgently needed. This review is intended to highlight the existing gaps in knowledge regarding phloem adaptation to extreme climate conditions prevailing at the high-elevation treeline and to serve as a stimulus to open up a new area of research.

\section{REFERENCES}

Agusti, J., and Greb, T. (2013). Going with the wind-Adaptive dynamics of plant secondary meristems. Mech. Dev. 130, 34-44. doi: 10.1016/j.mod.2012.05.011

Alfieri, F. J., and Evert, R. F. (1968). Seasonal development of the secondary phloem in Pinus. Am. J. Bot. 55, 518-528. doi: 10.2307/2440583

Alfieri, F. J., and Evert, R. F. (1973). Structure and Seasonal development of the secondary phloem in the Pinaceae. Bot. Gaz. 134, 17-25. doi: 10.1086/336674

Alvarez-Uria, P., and Körner, C. (2007). Low temperature limits of root growth in deciduous and evergreen temperate tree species. Funct. Ecol. 21, 211-218. doi: 10.1111/j.1365-2435.2007.01231.x

Alvarez-Uria, P., and Körner, C. (2011). Fine root traits in adult trees of evergreen and deciduous taxa from low and high elevation in the Alps. Alp. Bot. 121, 107-112. doi: 10.1007/s00035-011-0092-6

Antonova, G. F., and Stasova, V. V. (2006). Seasonal development of phloem in Scots pine stems. Russ. J. Dev. Biol. 37, 306-320. doi: 10.1134/ S1062360406050043

Antonova, G. F., and Stasova, V. V. (2008). Seasonal development of phloem in Siberian larch stems. Russ. J. Dev. Biol. 39, 207-218. doi: 10.1134/ S1062360408040024

Babushkina, E. A., Belokopytova, L. V., Zhimova, D. F., and Vaganov, E. A. (2019). Siberian spruce tree ring anatomy: imprint of development processes and their high-temporal environmental regulation. Dendrochronologia 53, 114-124. doi: 10.1016/j.dendro.2018.12.003

Caccianiga, M., Andreis, C., Armiraglio, S., Leonelli, G., Pelfini, M., and Sala, D. (2008). Climate continentality and treeline species distribution in the Alps. Plant Biosyst. 142, 66-78. doi: 10.1080/11263500701872416

Castagneri, D., Fonti, P., von Arx, G., and Carrer, M. (2017). How does climate influence xylem morphogenesis over the growing season? Insights from long-term intra-ring anatomy in Picea abies. Ann. Bot. 119, 1011-1020. doi: 10.1093/aob/mcw274

Cuny, H. E., Fonti, P., Rathgeber, C. B. K., von Arx, G., Peters, R. L., and Frank, D. C. (2019). Couplings in cell differentiation kinetics mitigate air temperature influence on conifer wood anatomy. Plant Cell. Environ. 42, 1222-1232. doi: $10.1111 /$ pce. 13464

Cuny, H. E., Rathgeber, C. B. K., Frank, D., Fonti, P., Mäkinen, H., Prislan, P., et al. (2015). Woody biomass production lags stem-girth increase by over one month in coniferous forests. Nat. Plants 1:15160. doi: 10.1038/NPLANTS.2015.16

De Schepper, V., De Swaef, T., Bauweraerts, I., and Steppe, K. (2013). Phloem transport: a review of mechanisms and controls. J. Exp. Bot. 64, 4839-4850. doi: $10.1093 /$ jxb/ert302

Deslauriers, A., Huang, J.-G., Balducci, L., Beaulieu, M., and Rossi, S. (2016). The contribution of carbon and water in modulating wood formation in black spruce saplings. Plant Physiol. 170, 2072-2084. doi: 10.1104/pp.15.01525

Epron, D., Dannoura, M., and Hölttä, T. (2019). Introduction to the invited issue on phloem function and dysfunction. Tree Physiol. 39, 167-172. doi: 10.1093/ treephys/tpz007

Evert, R. F. (1990). "Dicotyledons," in Sieve Elements. Comparative Structure, Induction and Development, eds H.-D. Behnke and R. D. Sjolund (Berlin: Springer-Verlag), 103-137.

Evert, R. F. (2006). Esau's Plant Anatomy. Meristems, Cells, and Tissues of the Plant Body: Their Structure, Function, and Development, 3rd Edn. Hoboken, NJ: John Wiley \& Sons, Inc.

\section{AUTHOR CONTRIBUTIONS}

Both authors listed have made a substantial, direct and intellectual contribution to the work, and approved it for publication.

\section{FUNDING}

The publication of this manuscript was financially supported by the University of Innsbruck.

Gindl, W., Grabner, M., and Wimmer, R. (2001). Effects of altitude on tracheid differentiation and lignification of Norway spruce. Can. J. Bot. 79, 815-821. doi: 10.1139/b01-060

Grace, J., Berninger, F., and Nagy, L. (2002). Impacts of climate change on the tree line. Ann. Bot. 90, 537-544. doi: 10.1093/aob/mcf222

Gričar, J., and Čufar, K. (2008). Seasonal dynamics of phloem and xylem formation in silver fir and Norway spruce as affected by drought. Russ. J. Plant Physiol. 55, 538-543. doi: 10.1134/S102144370804016X

Gričar, J., Čufar, K., Eler, K., Gryc, V., Vavrčík, H., de Luis, M., et al. (2021). Transition dates from earlywood to latewood and early phloem to late phloem in Norway Spruce. Forests 12:331. doi: 10.3390/f12030331

Gričar, J., Krže, L., and Čufar, K. (2009). Number of cells in xylem, phloem and dormant cambium in silver fir (Abies alba), in trees of different vitality. IAWA J. 30, 121-133. doi: 10.1163/22941932-90000208

Gričar, J., Prislan, P., De Luis, M., Gryc, V., Hacurova, J., Vavrčík, H., et al. (2015). Plasticity in variation of xylem and phloem cell characteristics of Norway spruce under different local conditions. Front. Plant Sci. 6:730. doi: 10.3389/fpls.2015. 00730

Gričar, J., Prislan, P., Gryc, V., Vavrčík, H., de Luis, M., and Čufar, K. (2014). Plastic and locally adapted phenology in cambial seasonality and production of xylem and phloem cells in Picea abies from temperate environments. Tree Physiol. 34, 869-881. doi: 10.3832/ifor1771-008

Gričar, J., Zupančic, M., and Čufar, K. (2007). Regular cambial activity and xylem and phloem formation in locally heated and cooled stem portions of Norway spruce. Wood Sci. Technol. 41, 463-475. doi: 10.1007/s00226-0060109-2

Gričar, J., Zupančic, M., Čufar, K., Koch, G., Schmitt, U., and Oven, P. (2006). Effect of local heating and cooling on cambial activity and cell differentiation in stem of Norway spruce. Ann. Bot. 97, 943-951. doi: 10.1093/aob/ mcl050

Gruber, A., Pirkebner, D., Oberhuber, W., and Wieser, G. (2011). Spatial and seasonal variations in mobile carbohydrates in Pinus cembra in the timberline ecotone of the Central Austrian Alps. Eur. J. For. Res. 130, 173-179. doi: 10. 1007/s10342-010-0419-7

Häsler, R. (1982). Net photosynthesis and transpiration of Pinus montana on east and north facing slopes at alpine timberline. Oecologia 54, 14-22. doi: 10.1007/ BF00541102

Häsler, R., Streule, A., and Turner, H. (1999). Shoot and root growth of young Larix decidua in contrasting microenvironments near the alpine timberline. Phyton $39,47-52$.

Hertel, D., and Schöling, D. (2011). Norway spruce shows contrasting changes in below- versus above-ground carbon partitioning towards the alpine tree line: evidence from a central European case study. Arct. Antarct. Alp. Res. 43, 46-55. doi: 10.1657/1938-4246-43.1.46

Hoch, G., and Körner, C. (2003). The carbon charging of pines at the climatic treeline: a global comparison. Oecologia 135, 10-21. doi: 10.1007/s00442-0021154-7

Hoch, G., and Körner, C. (2005). Growth, demography and carbon relations of Polylepis trees at the world's highest treeline. Funct. Ecol. 19, 941-951. doi: 10.1111/j.1365-2435.2005.01040.x

Hoch, G., and Körner, C. (2009). Growth and carbon relations of tree line forming conifers at constant vs. variable low temperatures. J. Ecol. 97, 57-66. doi: 10. 1111/j.1365-2745.2008.01447.x 
Hoch, G., and Körner, C. (2012). Global patterns of mobile carbon stores in trees at the high-elevation tree line. Glob. Ecol. Biogeogr. 21, 861-871. doi: 10.1111/j. 1466-8238.2011.00731.x

Hoch, G., Popp, M., and Körner, C. (2002). Altitudinal increase of mobile carbon pools in Pinus cembra suggests sink limitation of growth at the Swiss treeline. Oikos 98, 361-374. doi: 10.1034/j.1600-0706.2002. 980301.x

Holdheide, W. (1951). "Anatomie mitteleuropäischer Gehölzrinden (mit mikrophotographischem Atlas)," in Handbuch der Mikroskopie in der Technik, 5th Edn, ed. H. Freund (Frankfurt-am-Main: Unschau Verlag), 193-367.

Hölttä, T., Mencuccini, M., and Nikinmaaa, E. (2009). Linking phloem function to structure: analysis with a coupled xylem-phloem transport model. J. Theor. Biol. 259, 325-337. doi: 10.1016/j.jtbi.2009.03.039

Jensen, K. H., Liesche, J., Bohr, T., and Schulz, A. (2012). Universality of phloem transport in seed plants. Plant Cell. Environ. 35, 1065-1076. doi: 10.1111/j.13653040.2011.02472.x

Jyske, T., and Hölttä, T. (2015). Comparison of phloem and xylem hydraulic architecture in Picea abies stems. New Phytol. 205, 102-115. doi: 10.1111/nph. 12973

Jyske, T. M., Suuronen, J.-P., Pranovich, A. V., Laakso, T., Watanabe, U., Kuroda, K., et al. (2015). Seasonal variation in formation, structure, and chemical properties of phloem in Picea abies as studied by novel microtechniques. Planta 242, 613-629. doi: 10.1007/s00425-015-2347-8

Knoblauch, M., and Oparka, K. (2012). The structure of the phloem: still more questions than answers. Plant J. 70, 147-156. doi: 10.1111/j.1365-313X.2012. 04931.x

Knoblauch, M., and van Bel, A. J. E. (1998). Sieve tubes in action. Plant Cell 10, 35-50. doi: 10.2307/3870627

Kondhare, K. R., Patil, N. S., and Banerjee, A. K. (2021). A historical overview of long-distance signalling in plants. J. Exp. Bot. 72, 4218-4236. doi: 10.1093/jxb/ erab048

Körner, C. (1998). A re-assessment of high elevation treeline positions and their explanation. Oecologia 115, 445-459. doi: 10.1007/s004420050540

Körner, C. (2003). Carbon limitation in trees. J. Ecol. 91, 4-17. doi: 10.1046/j.13652745.2003.00742.x

Körner, C. (2012). Alpine Treelines. Functional Ecology of the Global High Elevation Tree Limits. Basel: Springer.

Körner, C. (2015). Paradigm shift in plant growth control. Curr. Opin. Plant Biol. 25, 107-114. doi: 10.1016/j.pbi.2015.05.003

Körner, C. (2021). Alpine Plant Life, 3rd Edn. Berlin: Springer.

Körner, C., and Paulsen, J. (2004). A world-wide study of high altitude treeline temperatures. J. Biogeogr. 31, 713-732. doi: 10.1111/j.1365-2699.2003. 01043.x

Kubisch, P., Leuschner, C., Coners, H., Gruber, A., and Hertel, D. (2017). Fine root abundance and dynamics of stone Pine (Pinus cembra) at the alpine treeline is not impaired by self-shading. Front. Plant Sci. 8:602. doi: 10.3389/fpls.2017. 00602

Lacombe, B., and Achard, P. (2016). Long-distance transport of phytohormones through the plant vascular system. Curr. Opin. Plant Biol. 34, 1-8. doi: 10.1016/ j.pbi.2016.06.007

Larcher, W. (2003). Physiological Plant Ecology. Ecophysiology and Stress Physiology of Functional Groups. Berlin: Springer-Verlag.

Larson, P. R. (1994). The Vascular Cambium: Development and Structure. Berlin: Springer-Verlag.

Leuschner, C., and Ellenberg, H. (2017). Ecology of Central European forests. Vegetation Ecology of Central Europe, Vol. 1. Berlin: Springer.

Liesche, J., Pace, M. R., Xu, Q., Li, Y., and Chen, S. (2017). Heightrelated scaling of phloem anatomy and the evolution of sieve element end wall types in woody plants. New Phytol. 214, 245-256. doi: 10.1111/nph. 14360

Liesche, J., Windt, C., Bohr, T., Schulz, A., and Hartvig Jensen, K. (2015). Slower phloem transport in gymnosperm trees can be attributed to higher sieve element resistance. Tree Physiol. 35, 376-386. doi: 10.1093/treephys/ tpv020

Lupi, C., Morin, H., Deslauriers, A., and Rossi, S. (2010). Xylem phenology and wood production: resolving the chicken-or-egg dilemma. Plant Cell. Environ. 33, 1721-1730. doi: 10.1111/j.1365-3040.2010.02176.x
Mayr, S., Schwienbacher, F., and Bauer, H. (2003). Winter at the Alpine timberline: why does embolism occur in Norway spruce but not in stone pine? Plant Physiol. 131, 780-792. doi: 10.1104/pp.011452

Mayr, S., Wolfschwenger, M., and Bauer, H. (2002). Winter-drought induced embolism in Norway spruce (Picea abies) at the Alpine timberline. Physiol. Plant 115, 74-80. doi: 10.1034/j.1399-3054.2002.1150108.x

McNairn, R. B. (1972). Phloem translocation and heat-induced callose formation in field-grown Gossypium hirsutum L. Plant Physiol. 50, 366-370. doi: 10.1104/ pp.50.3.366

Meentemeyer, V. (1977). "Climatic regulation of decomposition rates of organic matter in terrestrial ecosystems," in Proceedings of the Environmental Chemistry and Cycling Processes. Department of Energy Symposium Series CONF-760429, eds D. C. Adrians and I. L. Brisbin (Washington, DC: U.S. Department of Energy), 779-789.

Miller, T. W., Stangler, D. F., Larysch, E., Seifert, T., Spiecker, H., and Kahle, H. P. (2020). Plasticity of seasonal xylem and phloem production of Norway spruce along an elevational gradient. Trees 34, 1281-1297. doi: 10.1007/s00468-02001997-6

Montwe, D., Hacke, U., Schreiber, S. G., and Stanfield, R. C. (2019). Seasonal vascular tissue formation in four boreal tree species with a focus on callose deposition in the phloem. Front. For. Glob. Change 2:58. doi: 10.3389/ffgc.2019. 00058

Mullendore, D. L., Windt, C. W., Van As, H., and Knoblauch, M. (2010). Sieve tube geometry in relation to phloem flow. Plant Cell 22, 579-593. doi: 10.1105/tpc. 109.070094

Neuberger, D. S., and Evert, R. F. (1975). Structure and development of sieve areas in the hypocotyl of Pinus resinosa. Protoplasma 84, 109-125. doi: 10.1007/ BF02075947

Palacio, S., Hoch, G., Sala, A., Körner, C., and Millard, P. (2014). Does carbon storage limit tree growth? New Phytol. 201, 1096-1100. doi: 10.1111/nph. 12602

Pfautsch, S., Hölttä, T., and Mencuccini, M. (2015). Hydraulic functioning of tree stems-fusing ray anatomy, radial transfer and capacitance. Tree Physiol. 35, 706-722. doi: 10.1093/treephys/tpv058

Plomion, C., Leprovost, G., and Stokes, A. (2001). Wood formation in trees. Plant Physiol. 127, 1513-1523. doi: 10.1104/pp.010816

Prislan, P., Gričar, J., de Luis, M., Smith, K. T., and Čufar, K. (2013). Phenological variation in xylem and phloem formation in Fagus sylvatica from two contrasting sites. Agric. For. Meteorol. 180, 142-151. doi: 10.1016/j.agrformet. 2013.06.001

Prislan, P., Mrak, P., Žnidaršič, N., Štrus, J., Humar, M., Thaler, N., et al. (2019). Intra-annual dynamics of phloem formation and ultrastructural changes in sieve tubes in Fagus sylvatica. Tree Physiol. 39, 262-274. doi: 10.1093/treephys/ tpy102

Rosner, S., Baier, P., and Kikuta, S. (2001). Osmotic potential of Norway Spruce (Picea abies (L.) Karst.) secondary phloem in relation to anatomy. Trees 15 , 472-482. doi: 10.1007/s00468-001-0131-9

Rossi, S., Deslauriers, A., Anfodillo, T., and Carraro, V. (2007). Evidence of threshold temperatures for xylogenesis in conifers at high altitudes. Oecologia 152, 1-12.

Rossi, S., Deslauriers, A., Anfodillo, T., Morin, H., Saracino, A., Motta, R., et al. (2006). Conifers in cold environments synchronize maximum growth rate of tree-ring formation with day length. New Phytol. 170, 301-310. doi: 10.1111/j. 1469-8137.2006.01660.x

Rossi, S., Deslauriers, A., Gričar, J., Seo, J. W., Rathgeber, C. B. K., Anfodillo, T., et al. (2008). Critical temperatures for xylogenesis in conifers of cold climates. Glob. Ecol. Biogeogr. 17, 696-707. doi: 10.1111/j.1466-8238.2008. 00417.x

Ryan, M. G., and Robert, E. M. R. (2017). Zero-calorie sugar delivery to roots. Nat. Plants 3, 922-923. doi: 10.1038/s41477-017-0070-0

Salmon, Y., Dietrich, L., Sevanto, S., Hölttä, T., Dannoura, M., and Epron, D. (2019). Drought impacts on tree phloem: from cell-level responses to ecological significance. Tree Physiol. 39, 173-191. doi: 10.1093/treephys/ tpy153

Savage, J. A., and Chuine, I. (2021). Coordination of spring vascular and organ phenology in deciduous angiosperms growing in seasonally cold climates. New Phytol. 230, 1700-1715. doi: 10.1111/nph.17289 
Savage, J. A., Clearwater, M. J., Haines, D. F., Klein, T., Mencuccini, M., Sevanto, S., et al. (2016). Allocation, stress tolerance and carbon transport in plants: how does phloem physiology affect plant ecology? Plant Cell. Environ. 39, 709-725. doi: $10.1111 /$ pce. 12602

Schenker, G., Lenz, A., Körner, C., and Hoch, G. (2014). Physiological minimum temperatures for root growth in seven common European broad-leaved tree species. Tree Physiol. 34, 302-313. doi: 10.1093/treephys/ tpu003

Schulz, A., and Thompson, G. A. (2009). Phloem Structure and Function: Encyclopedia of Life Sciences (eLS). 2nd Edn, Wiley. doi: 10.1002/ 9780470015902.a0001290.pub2

Sevanto, S. (2018). Drought impacts on phloem transport. Curr. Opin. Plant Biol. 43, 76-81. doi: 10.1016/j.pbi.2018.01.002

Swidrak, I., Gruber, A., and Oberhuber, W. (2014). Xylem and phloem phenology in co-occurring conifers exposed to drought. Trees 28, 1161-1171. doi: 10.1007/ s00468-014-1026-x

van Bel, A. J. E. (1990). Xylem-phloem exchange via the rays: the undervalued route of transport. J. Exp. Bot. 41, 631-644. doi: 10.1093/jxb/41. 6.631

van Bel, A. J. E. (2003). The phloem, a miracle of ingenuity. Plant Cell. Environ. 26, 125-149. doi: 10.1046/j.1365-3040.2003.00963.x

Wang, Y., Čufar, K., Eckstein, D., and Liang, E. (2012). Variation of maximum tree height and annual shoot growth of Smith fir at various elevations in the Sygera Mountains, southeastern Tibetan Plateau. PLoS One 7:e31725. doi: 10. 1371/journal.pone.0031725

Weih, M., and Karlsson, P. S. (2001). Growth response of mountain birch to air and soil temperature: is increasing leaf-nitrogen content an acclimation to lower air temperature? New Phytol. 150, 147-155. doi: 10.1046/j.1469-8137.2001. 00078.x

Weih, M., and Karlsson, P. S. (2002). Low winter soil temperature affects summertime nutrient uptake capacity and growth rate of mountain birch seedlings in the subarctic, Swedish Lapland. Arct. Antarct. Alp. Res. 34, 434-439. doi: $10.1080 / 15230430.2002 .12003514$

Weng, J. H., Liao, T. S., Sun, K. H., Chung, J. C., Lin, C. P., and Chu, C. H. (2005). Seasonal variations in photosynthesis of Picea morrisonicola growing in the subalpine region of subtropical Taiwan. Tree Physiol. 25, 973-979. doi: 10.1093/treephys/25.8.973

Conflict of Interest: The authors declare that the research was conducted in the absence of any commercial or financial relationships that could be construed as a potential conflict of interest.

Publisher's Note: All claims expressed in this article are solely those of the authors and do not necessarily represent those of their affiliated organizations, or those of the publisher, the editors and the reviewers. Any product that may be evaluated in this article, or claim that may be made by its manufacturer, is not guaranteed or endorsed by the publisher.

Copyright $\odot 2021$ Schröter and Oberhuber. This is an open-access article distributed under the terms of the Creative Commons Attribution License (CC BY). The use, distribution or reproduction in other forums is permitted, provided the original author(s) and the copyright owner(s) are credited and that the original publication in this journal is cited, in accordance with accepted academic practice. No use, distribution or reproduction is permitted which does not comply with these terms. 